$\mathrm{Cl}$ ass aver age score for teacher support and rel i ef of depressi on in adol escents: A popul at $\mathrm{i}$ on study i $\mathrm{n}$ Japan

\begin{tabular}{|l|l|}
\hline 著者 & 水田 明子 \\
\hline 発行年 & 2015- 12-11 \\
\hline URL & ht t p: //hdl . handl e. net /10271/2916 \\
\hline
\end{tabular}


博士 (医学) 水田 明子

論文題目

Class average score for teacher support and relief of depression in adolescents: A population study in Japan

(クラス平均でみた教員からのサポートと思春期の抑うつ緩和: 日本における地域集団 研究）

論文の内容の要旨

[はじめに

欧米の疫学研究では思春期の大うつ病の有病率は 2.0 8.0\%で、青年の $20 \%$ が抑 うつや不安の精神的健康問題を経験している。日本の 10 歳から 14 歳の死因順位の 第 2 位は自殺で、15 歳は自殺が第 1 位であり、自殺の主因である大うつ病の時点有 病率は 12〜14 歳で 4.9\%、抑うつ傾向は小学生の $7.8 \%$ から学生では $22.8 \%$ に急増 する。欧米では教員からのサポートと生徒の抑うつとの関連について報告されている が、教育体制の異なる日本での研究は少なく、標本が小さく学年が限定されている。 本研究の目的は、潜在的な交絡因子を調整して教員からのサポートによる中学生の 抑うつ緩和効果を明らかにすることである。

[材料ならびに方法]

静岡県の 2 市にある全ての公立中学校 8 校で、全学年の生徒とクラス担任に 2012 年 12 月から 2013 年 1 月に質問紙調査を行った。文書で説明を行い、同意が得られ た者に無記名式自記式調査票への回答を求めた。調査対象の生徒は 2,968 人であり、 授業時間内に調査を行った。調査対象のクラス担任は 97 人で、プライバシーの守られ る場所で都合の良い時間に回答した。

生徒には抑うつ、教員からのサポート、成績満足度、経済状況、性、学年、家族構成 を調査した。クラス担任からは性と教職経験年数を把握した。うつ病のスクリーニングテ ストであるBirleson の Depression Self-Rating Scale for Children (DSRS-C) 日本語版を 用いた。18 項目 3 段階評価で、日本語版のカットオフ值 16 点未満を抑うつ低值、16 点以上を高值とした。教員からのサポートは中学生用 The Scale of Expectancy for Social Support (SESS)を用いた。16 項目 4 段階評価で、得点が高いほど教員からのサ ポートが高いことを示す。個々の生徒の評価を“個人が感じる教員サポート”とし、第 3 四分位数の 51 点未満を低值、51 点以上を高值とした。個々の生徒の評価についてク ラス単位の平均值を算出し、クラス担任のサポート力を表す変数として“クラス平均で みた教員サポート”とした。これは、抑うつのある生徒がサポートを過剰に又は過小に 評価するといら因果の逆転を防ぐことを意図した。第 3 四分位数の 44.6 点未満を低值、 44.6 点以上を高值とした。成績満足度は 4 件法、経済状況は 5 件法で尋ね低群と高 群に分けた。家族構成は実両親との同居、同居以外に分けた。クラス担任の教職経 験年数は 10 年未満と 10 年以上に分け、クラスの生徒のデータに結合した。クラス平均 
でタた教員サポートを説明変数、抑うつを目的変数とし、個人の感じる教員サポート、 成績満足度、経済状態、生徒の性、学年、家族構成、クラス担任の性と教職経験年数 を調整したロジスティック回帰分析を行った。さらに、成績満足度、生徒の性、経済状 態についてクラス平均でみた教員サポートとの交互作用項を作成し評価した。加えて、 生徒の成績満足度、生徒の性、経済状態で其々層化した分析を行った。本研究は、 浜松医科大学医の倫理委員会の承認を得て行った(24-147)。

[結果]

うつ病のスクリーニングテストと性の項目に欠損のない分析対象生徒数は 2,780 人 で有効回答率は $93.7 \%$ であった。抑うつ高值は全体の $25.0 \%$ (男 $18.8 \%$ 、女 $31.4 \%$ ) で あった。クラス平均でみた教員サポートと個人の感じる教員サポートの相関係数は $\mathrm{r}=0.317$ であった。交絡因子を調整したロジステイック回帰分析の結果、クラス平均で みた教員サポート高值 (オッズ比 $(\mathrm{OR})=0.739,95 \%$ 信頼区間 $(\mathrm{CI})=0.575-0.948)$ 、個人 が感じる教員サポート高值 $(\mathrm{OR}=0.358,95 \% \mathrm{CI}=0.267-0.479)$ 、成績満足度高群 （OR=0.406，95\%CI=0.320-0.516）、経済状況高群（OR=0.432，95\%CI=0.344-0.543） は抑うつと有意な負の関連があった。さらに、クラス平均でみた教員サポート高值と成 績満足度高群の交互作用が有意であった $(\mathrm{P}=0.025)$ 。生徒の性、経済状況との交互 作用は有意でなかった。

[考察]

本研究はクラス平均でみた教員サポートが高いと抑うつは有意に低いことを明らか にした。クラス担任による生徒のメンタルヘルスの支援が重要であることが示唆された。 教員からのサポートと思春期のメンタルヘルスに焦点を当てた日本で初めての大規模 研究であり、クラス平均でみた教員サポートを用いて抑うつとの関連を検討した研究は 我々の知る限り本研究が初めてである。さらに、クラス平均でみた教員サポートと成績 満足度の交互作用を明らかにした。成績満足度が高く、クラス平均で夕た教員サポー 卜が高いクラスの生徒ほど抑うつが少ない一方で、成績満足度の低い生徒においては クラス担任によるサポートが生徒のメンタルヘルスに十分な効果を発揮していない可 能性が示唆された。成績満足度と教員からのサポートの交互作用を明らかにした先行 研究はないため、この新たな知見について教育体制の異なる世界の他の国でも同様 の研究が行われることを期待したい。

\section{[結論 $]$}

クラス担任には生徒のメンタルヘルスーの影響を認識し対応する役割と、成績満足 度の低い生徒への支援の強化が求められる。本研究は、クラス単位での生徒のメンタ ルヘルスのポピュレーションアプローチの促進に貢献できる。 